Portland State University

PDXScholar

2-25-1986

\title{
Daycare Center Services for the Handicapped in the Portland Metropolitan Area: A Descriptive Study
}

Jacqueline A. Freni-Rothschild

Portland State University

Follow this and additional works at: https://pdxscholar.library.pdx.edu/open_access_etds

Part of the Disability and Equity in Education Commons

Let us know how access to this document benefits you.

\section{Recommended Citation}

Freni-Rothschild, Jacqueline A., "Daycare Center Services for the Handicapped in the Portland Metropolitan Area: A Descriptive Study" (1986). Dissertations and Theses. Paper 3598.

https://doi.org/10.15760/etd.5482

This Thesis is brought to you for free and open access. It has been accepted for inclusion in Dissertations and Theses by an authorized administrator of PDXScholar. Please contact us if we can make this document more accessible: pdxscholar@pdx.edu. 
AN ABSTRACT OF THE THESIS OF Jaoqueline A. Freni-Rothschild for the Master of Science in Education presented February 25, 1986.

Title: Daycare Center Services for the Handicapped in the Portland Metropolitan Area: A Descriptive Study.

APPROVED BY MEMBERS OF THE THESIS COMMITTEE:

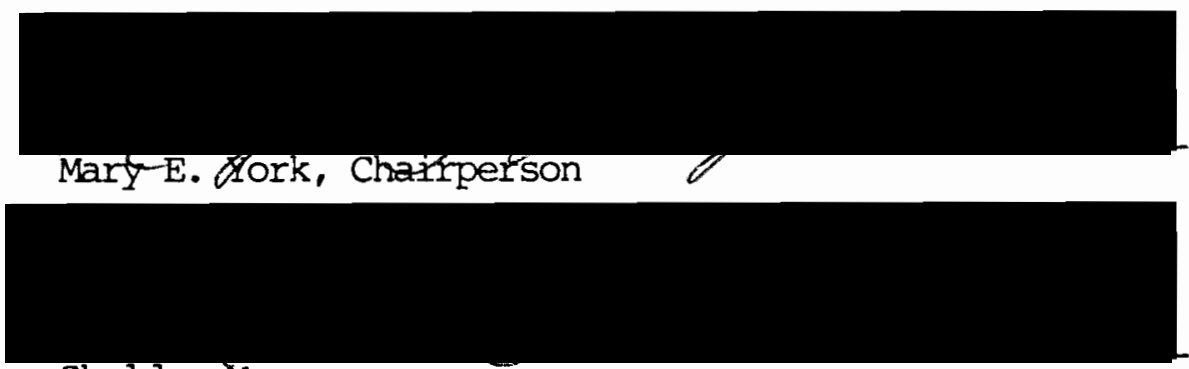

Sheldon Maron

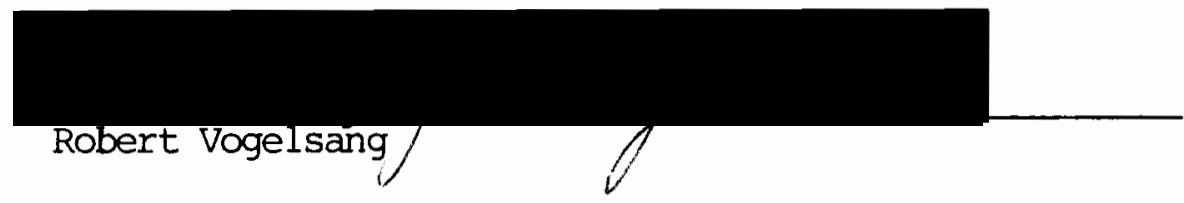

Because more and more women are giving up traditional roles to join the work force, daycare is becoming a major concern in the U.S. today. In the Portland Metro area alone are estimated to be approximately 64,000 children who require daycare. Statistics show that daycare centers are the preferred source of daycare when cost is not prohibitive.

This study endeavors to identify those daycare centers in the Portland Metro area that provide service to the handicapped or special needs child. ("Special needs" refers to children that are handicapped with varying degrees of severity.) It discusses the value and importance of 
the daycare experience for the young child, noting that daycare options available to the normal child are not usually available to the atypical child.

Citing and summarizing related literature, the study states that daycare staff development aimed at increasing service to the handicapped is a reasonable and attainable goal. This study goes on to make specific suggestions in that regard.

The research instrument was a short questionnaire with questions regarding services for special needs children at each center. Two sets of questionnaires were sent to the centers and then follow-up phone calls were made to selected centers. One hundred and one daycare centers were included in the study. It was learned that 40 centers are currently serving some kind of special need child, 20 are willing to serve them, but have none enrolled, and 41 do not accept handicapped children into the center. There are 88 special needs children enrolled in the 40 centers. The kinds of handicapped children enrolled vary and, according to the data gathered, they are predominately in the mild to moderate range in degree of severity.

The reason most frequently given for not serving the handicapped was staffing. Expense is also a major concern along with lack of experience and knowledge. 
DAYCARE CENTER SERVICES FOR THE HANDICAPPED

IN THE PORTLAND METROPOLITAN AREA:

A DESCRIPTIVE STUDY

by
JACQUELINE A. FRENI-ROTHSCHILD

A thesis submitted in partial fulfillment of the requirements for the degree of

\author{
MASTER OF SCIENCE \\ in \\ EDUCATION
}

Portland State University

1986 
TO THE OFFICE OF GRADUATE STUDIES AND RESEARCH:

The members of the Committee approve the thesis of

Jacqueline A. Freni-Rothschild presented February 25, 1986.

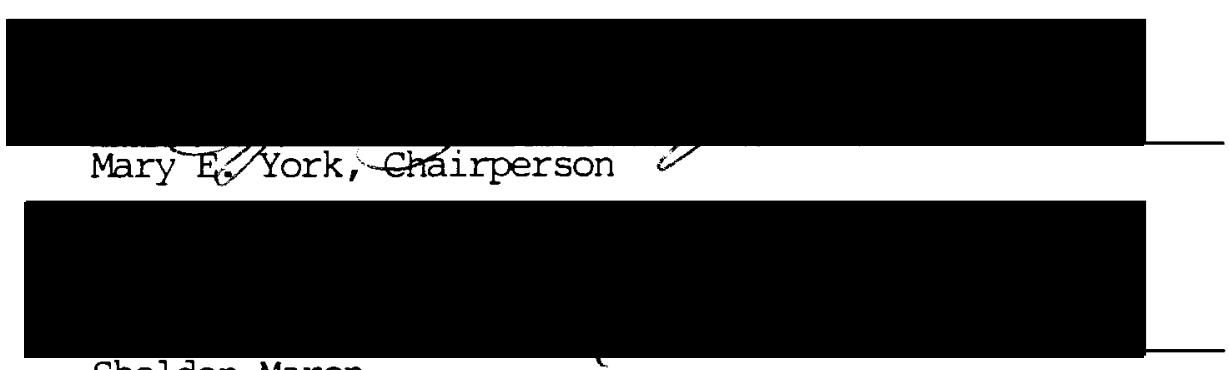

Sheldon Maron

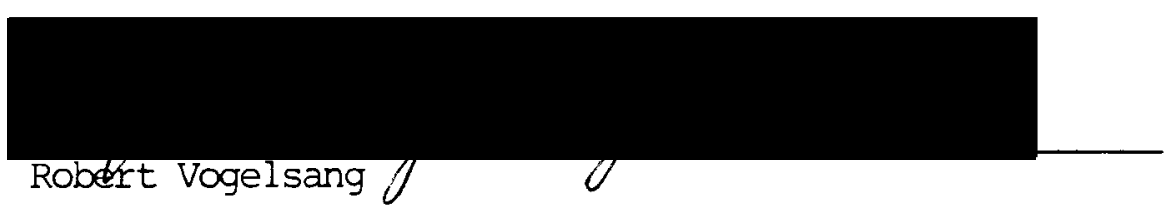

APPROVED:

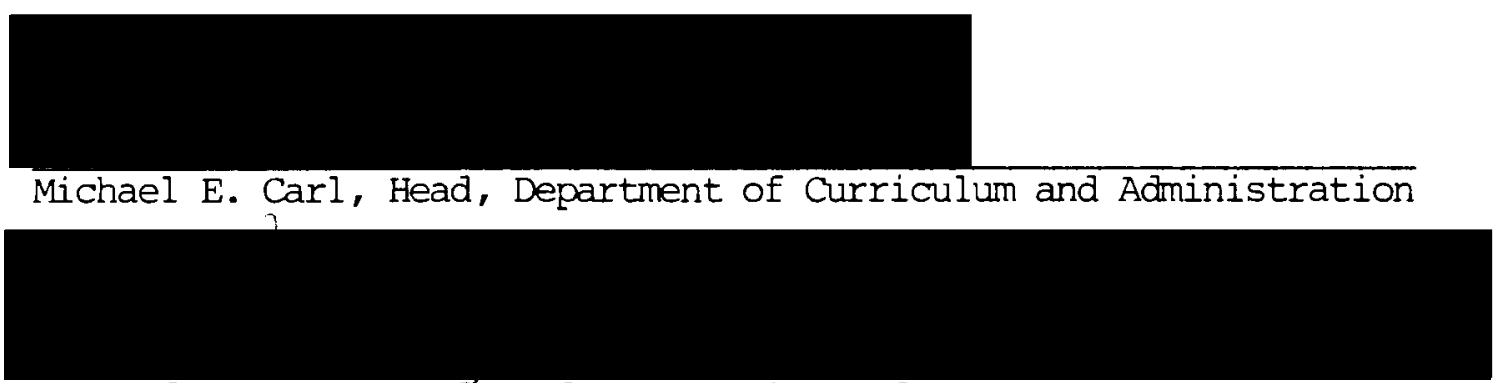

Bernard Ross, Dean of Graduate Studies and Research 


\section{ACKNOWLEDGEMENTS}

Dr. Mary E. York for urging me to write a thesis and offering encouragement and guidance throughout.

My husband, Keith Rothschild, for his constant support, advice and house-husbandry.

All my special children who over the years have inspired me, opened my eyes to and shared their world with me; and for whom I seek the answers. 
TABIE OF CONTENTS

PAGE

ACKNOWLEDGEMENTS . . . . . . . . . . . . . . . .

LIST OF TABIES

LIST OF FIGURES

CHAPTER

I INTRODUCTION . . . . . . . . . . . . . .

Background . . . . . . . . . . . . . .

Problem . . . . . . . . . . . . . . .

II REIATED LITERATURE . . . . . . . . . . . . . 9

III PROCEDURES . . . . . . . . . . . . . . . 22

IV RESULTS . . . . . . . . . . . . . . . . 28

Number of Daycare Centers Accepting Handicapped Children

Conditions for Accepting Handicapped Children .

Types of Handicaps Found in Centers . . . . .

Daycare Centers Not Serving the Handicapped . .

Age of Children in Daycare Centers . . . . .

Kindergarten Programs in Daycare Centers . . .

$\mathrm{V}$ CONCLUSIONS AND DISCUSSIONS . . . . . . . . . 


\section{LIST OF TABLES}

TABLE

PAGE

I The Number of Centers that Accept Special Needs

Children and the Degree of Severity They

Will Serve . . . . . . . . . . . .

II Conditions for Accepting Special Needs Children and

Degrees of Severity Served . . . . . . . . .

III Kinds of Handicaps Currently Served in Daycare

Centers . . . . . . . . . . . . . . .

IV Reasons for not Accepting Special Needs Children

Into Daycare Centers . . . . . . . . . .

V Number of Centers that Serve Special Needs Children

by Age ............ . . . . . . .

VI Percent of Centers that Accept Mild, Moderate and

Severe Handicapped Children . . . . . . . .

VII Number of Centers by Age Range Served . . . . . . . 


\section{LIST OF FIGURES}

FIGURE

PAGE

1. Questionnaire ..................

2. Letter . . . . . . . . . . . . . . .

3. Minimum Ages of Children in Daycare Centers . . . . .

4. Maximum Ages of Children in Daycare Centers . . . . .

5. Comparison of the Percentage of Population of Each Handicap for Each Degree of Severity . . . . . . 
CHAPTER I

\section{INTRODUCTION}

\section{Background}

Daycare is a major concern in the U.S. today. For the first time in history 52 percent of U.S. women are employed, with an anticipated increase to 65 percent by $1995 .^{1}$ Therefore, daycare for young children is becoming a more common, if not accepted, practice. In March 1981, 53 percent of children eighteen years and under were involved in daycare, with 43 percent of those between the ages of infancy and six years old needing full-time daycare. 2

In Oregon, the number of women working has increased dramatically since the 1970s. Approximately 70,000 working Oregon women have children under the age of $\operatorname{six}^{3}$ and if that is consistent with the national estimate of 43 percent, that means that there are 63,609 children in the Portland Metropolitan area that require child care.

Daycare refers to any means of child care that occurs outside the home while parents are involved in work, school, etc. The normal child will spend from four to ten hours daily in this daycare

$1_{\text {City Club of Portland. Report on Child Care Needs of working }}$ Parents in the Portland Metro Area, 1983, p. 257.

${ }^{2}$ City Club of Portland, pp. 260-61.

${ }^{3}$ City club of Portland, p. 261. 
environment. ${ }^{4}$ There are a variety of child care options available to parents and families, depending on needs, economics and living situations. These include 1) family daycare, 2) daycare centers, 3) a combination of both one and two and 4) cooperative daycare.

Family daycare includes any out-of-home care in a family setting by an unrelated individual . . Family care providers may often care for three to four children under the age of six, including their own preschoolers. 5

Although the number of children allowed per home is regulated by state laws, ${ }^{6}$ the majority of these homes are not registered with, or licensed by, the state. The hours and fees in family daycare are flexible and are set by the provider. This kind of daycare is most widely available.

Daycare centers are generally operated for a large number of children (20-120) in a setting designed to accommodate both the children and the staff adequate to provide this service. Many centers also provide a kindergarten experience. The number of staff is regulated by state law and centers must be registered and licensed by the state. Centers usually operate on a regular schedule $(6$ a.m. to 6 p.m.) and have fixed rates for child care. In Portland (until 1981), most centers used a sliding scale from $\$ 7$ to $\$ 15$ daily. In October 1981, 25 percent of the children in oregon received care in centers. In 1980 there was a drastic reduction in state subsidies to child care

${ }^{4}$ Sauer, Ruth Barrymore, Handicapped Children and Daycare Bank Street College of Education, New York, New York March 1975.

${ }^{5}$ City Club of Portland, p. 259.

${ }^{6}$ Oregon. Legislative Assembly Oregon Revised Statues Legislative Counsel Camittee Vol 3A, 1985. 
centers. Prior to this reduction, 49 percent of the children in child care received service in centers, which indicates that, when cost was not a factor, one half of the served population preferred center daycare settings. ${ }^{7}$

Combined child care (center and family daycare) works a little differently. Primary care comes from the family daycare provider, with additional participation in centers one to two days a week for a specified period of time each day. This additional participation is extremely important if the family is to experience any continuity in their child care. The reasons for this are several in number. First, the homes that provide family daycare are sometimes unsatisfactory to the parents. Also, the quality of environment and care vary widely from home to home and, even when licensed by the state, these homes are not obliged to meet rigorous standards of quality. Therefore, families are often inclined to change from home to home in search of the right situation for their child.

Cooperative child care involves a kind of barter system. Parents participate with their time to provide care for a group of children. Usually no fee is required, but parents must be involved for a fixed number of hours per week in return for child care. Therefore, this is not a viable option for most parents whose work hours are the standard 8 a.m. to 5 p.m. 
$\underline{\text { Problem }}$

The focus of this study is on daycare centers, and only those daycare centers operating in the Portland Metropolitan area. This angle of inquiry was selected because there are large groups of young children participating in early childhood/preschool experiences. This study will address only the services of daycare/preschool environments available to young children ages birth to six, and the special needs young children in particular. "Special needs" indicates children who are atypical and require a little more care, attention and staff experience, and may include children with special diets, nonEnglish speaking children and children with speech problems. This may also include children with distinguishing characteristics such as a physical handicap or mental retardation. "Special need" is not defined to any degree or intensity in the daycare system. Special need children are all considered to be one and the same in need. For the purposes of this study "special need" refers to any moderately to severely handicapped child, i.e., mentally retarded, physically handicapped, multi-handicapped, sight impaired, hearing impaired, and emotionally disturbed.

Whatever the reason for which parents choose their daycare setting, the daycare center experience is, for many young children, the beginning of socialization, development of language skills and an introduction to preschool activities. That is, for normal children. But what happens to a young severely handicapped child and his family? What provisions, if any, are there for this child? What kinds of daycare options are available to this family? The trauma of a 
handicapped child is enough for a family to suffer without the additional fact of life that their circumstances and life choices are gravely affected. A decision regarding daycare can influence career choices, and can cause one parent of a two working parent family to abandon their job. Family conditions, style of living and level of stress that a special family experiences all conspire to disrupt the family dynamics. What can the parent do to develop the kinds of supports needed to continue with a "normal" life? Without the support of daycare services such a family can be disrupted to the point of confusion and dissolution, resulting in the institutionalization of the severely handicapped child. This is done for lack of a better alternative.

A severely handicapped child is defined as one who has a major deficit in more than one area of development, i.e., language, motor, self-help and socialization skills. The deficits are described in developmental terms since the focus is on developmental programs (preschool environments).

Studies suggest that exposure to normal environments promote the development of the child. ${ }^{8}$ Also, with repeated practice the severely handicapped can learn. Passage of P.L. 94-142, in 1975, opened the door for the handicapped to enter public schools. It gave them the same right to a free and equal education as their non-handicapped counterparts. Today there is an emphasis on mainstreaming in school programs. Mainstreaming implies that the child will spend the bulk of his day with

8 Wolfensberger, w. "The Principle of Normalization in Human Services," National Institute on Mental Retardation, Toronto, Canada: 1972, pp. 122-135. 
normal peers. However, young handicapped children (birth to six years) are often isolated from their peers for most of their early years. Even if a handicapped child is lucky enough to live in a school district that serves youngsters three to six years old, he is restricted to "special" classes or programs for most of the short three to fours hours of his day there. Obviously, his integration with peers is minimal. For the most part, the focus of these "special" programs is on the handicapping condition, how to deal with it, change it, develop alternatives to cope with it and to teach basic skills in isolation from real life experiences. These programs accept only handicapped children and many of them are situated in such a manner as to preclude any mainstreaming with normal peers. Parent participation is a requirement for many programs and extended daycare simply is not offered. Therefore, a parent must be available if these support services are to be utilized.

It is not until the age of six or seven that a handicapped child enters a setting with normal peers, consequently the young handicapped child is denied the social interactions with peers in his early years and hence a major facet in the development of values, behaviors and habits is lost to the child. Special families are also denied the support and respite that daycare centers provide to other families on a continuous and reliable schedule. Contact with peers may increase after age six, but the severely handicapped youngster has already missed the early childhood experiences available to 50 percent of his peers.

There are more similarities than differences between handicapped and normal children. Young handicapped children are children first, 
handicapped second. It is also suggested that severely handicapped children are not readily accepted into daycare centers in the Portland Metropolitan area. Daycare operators feel that 1) they are not equipped to meet the needs of "special" children, 2) they need additional "specially trained" staff to care for the special needs child and 3) that this requires costly capital outlay and budget risks. The centers believe that experts in Special Education can better serve these children, but these experts may have no experience with early childhood programs and work only with the handicap and not the whole person. Again, the young severely handicapped child goes without services offered to his normal peers.

This study is designed to poll the daycare centers in the Portland Metropolitan area to see which centers, if any, provide service to the young severely handicapped child or to any young handicapped child. It will help to assess the number of special needs children being served in centers today and the types of handicapped children who are more readily accepted into daycare centers. It is hoped that this will identify the trends or attitudes about particular handicaps. It is this researcher's opinion that centers are more readily available to the mildly handicapped because such children are not as apparently disabled as the severely handicapped and are more easily mainstreamed.

Daycare centers seem to be the logical place to begin to mainstream young handicapped children. Devolck (1966) suggests that it is also economical to mainstream young children rather than provide 
separate programs, but before these issues can be explored it is important to know what already exists for the population.

This study seeks to answer these questions:

1. What centers provide care for young handicapped children?

2. What centers provide care for moderately to severely handicapped children?

3. What kinds of handicapping conditions do daycare centers accept?

4. What degrees of severity are acceptable to daycare centers?

5. What requirements do daycare centers have for acceptance of handicapped children?

6. What services are offered by those centers that do accept handicapped children? 
CHAPTER II

RELATED LITERATURE

The Education of the Handicapped Act, P.L. 94-142, mandates education for all children ages 3 through 21 years. The law applies specifically to handicapped children. Its implementation in the past 11 years has been slow and inconsistent. To date, 42 states offer some form of education for the young handicapped child under five, but this is limited in scope and does not embrace the full spectrum of handicapped students. In addition, only seven states offer this service to handicapped children under the age of two. ${ }^{9}$ It is interesting to note that in the entire country we know only the number of young handicapped children we serve. No where was this researcher able to find an estimate of the number of young handicapped children living.

Yet the need is great. The earlier start these children get in their education and living skills, the greater the chance there is for them to become functioning and productive adults. For their parents, childcare is needed to provide relief from the continued care these children require. We should have daygare space available for the family ....

${ }^{9}$ Seventh Annual Report to Congress on Implementation of the Education of the Handicapped Act, U.S. Department of Education, 1985.

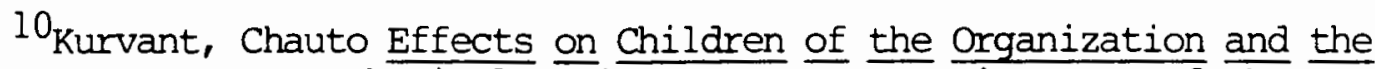
Design of the Daycare Physical Environment: Appropriateness of the Inter Agency Daycare Requirements, 1976, p. 23. 
Sauer (1975) has developed a handbook for parents of handicapped children and for the staff of daycare centers in the New York area; and she reminds us that it is essential that handicapped and nonhandicapped children be brought together in the learning environment. Sauer insists that the emphasis should be on helping the children that are different, rather than seeking to isolate them. She reminds us that all children grow and develop at their own rate and that separating young handicapped children from their normal peers is, for many reasons, unhealthy: 1) this separation isolates children from contact with other children, a sword with two edges--one side cutting into the handicapped childs education, and the other truncating the normal child's experience of the world; 2) it does not allow the child an opportunity to strive for acceptance from non-handicapped peers, thereby denying this individual a most valuable asset--developed coping skills; 3) it supports and perpetuates a trend, or theme, of historical wisdom, to wit, that families with special children must seek the special environment and the special professional to specially treat their special child. Parents are conditioned from the birth of their child to believe that this is the only avenue for their particular dilemma. Consequently, while normal peers are daily meeting life's daily challenges, the handicapped child is taught that the only resistance in their atmosphere comes from themselves; 4) and finally, Sauer says, this separation only serves to reinforce an already wellentrenched belief in our society that the present no-challenge-allsupport system works and must not be tampered with. 
As can be seen, Sauer's suggestions for integrating young handicapped and non-handicapped children has merit. It allows children without handicaps to learn some facts about their world, i.e., about the different children in it. It promotes in young children the development of tolerance and understanding, the absence of which is well witnessed in our schools today. It also allows both groups of children to grow toward appreciation of each other and to establish peer relationships with each other. Such an environment would stimulate a learning process wherein children would learn both socially and intellectually from one another.

Sauer, in her handbook, of fers many suggestions for opening up the current daycare situation in order to permit changes to take place. She states that integration of the handicapped with the nonhandicapped child must begin now and she offers concrete ideas as steps to this goal. For example, staff discussions of fears and prejudices in regard to special children would be a useful opener. Parent involvement in policy development is another approach. Staff could invite parents to bring ideas, input of any nature, to help staff better understand the special child. Staff must themselves learn and delineate their own limitations, comfort zones, in regard to their involvement with the handicapped. Parents, for their part, could become members of boards, daytime participants in the program and resource developers in the community. Staff and parents could seek and introduce outside authorities, volunteer consultants and any and all available resources in their community. 
Davis (1978) raises the question of how to work with young children and she evaluates two methods of teaching, the traditional and the humanistic. This question comes to be posed as a result of the introduction of mainstreaming into the education process. "Mainstreaming [is the] designing of the education program to meet the optimum potential for learning of each child ...."ll

Humanistic education is focused on the total person and concerns itself with providing learning experiences which allow children in all stages of growth to develop in their unique way. The humanistic approach shapes the learning process in meaningful experiences that enable the child to adapt. This system is designed to help the individual meet his/her own needs and aspirations. Traditional learning is directed toward shaping the individual to meet the needs and perpetuate the values of society. Traditional education involves the aquisition of basic skills to survive in society.

It is assumed that what Davis means is that the handicapped child needs to be trained in basic skills while encountering real life. The skills become meaningful because the child is allowed to exercise them in real life experiences rather than in the artificial world of the old school.

They have conditions which preclude the development of skills in the domain of learning and demand special teaching. [Thus] a more humanistic

${ }^{11}$ Davis, Bette Jœ, and Jacquel ine Blackwell, "Humanistic Education and the Handicapped Child: Implications for Quality Day Care Programs," 1978 p.4. 
approach . . . will be needed to teach these children to learn ... to integrate a sense of self

"Learning is developmental and requires sequential approaches to attain success" says Davis, and she goes on to say that, "According to Piaget, the first two years of life are spent in collecting and interpreting information taken in through the senses."13 when deprived of our sensory pathways, we can expect a profound impact on total learning potential.

For the mentally retarded as well as the normal individual the periods of human life are not isolated from one another. Every period forms the basis for the succeeding one and ... the stronger the basis the better preparation for the next stage
of growth.

When a child performs in the retarded range, other areas of their development beside IQ need to be addressed. All the effects that a handicapping condition have on a child's development are not known, but it is a certainty that the condition does color more than one area of the behavioral profile.

Wolfensberger (1972) addresses the idea of the effect of total development when he speaks about the normalizing principle and, in particular, about activation. Activation, a Scandinavian term, is the "involvement of persons in meaningful and hopefully normalizing activities and implies motor involvement and ambulation or at least

12 Davis, p. 2.

$13_{\text {Davis p. } 56 .}$

14 DeVolck, I., "The Preschool Child Goes to School: A Special Kindergarten Program in the Netherlands," International Child Welfare Review 19, 1966 p. 183. 
mobility."15 In Scandinavia, handicapped individuals, both ambulatory and non-ambulatory, are integrated and encouraged, indeed expected, to explore their environment by any means at their disposal including special and adaptive equipment. This places the non-ambulatory person in a more normal environment where he/she is more likely to participate in ongoing activities, engage in more movement and, perhaps, even become ambulatory or at least mobile. All this "ambulation, mobility and normalization . . [ is occurring] without application of operant conditioning . . . "16

Several studies have looked at the behavioral changes that result when integration of handicapped and non-handicapped has occurred. Fredricks (et al. 1978) indicates that

in an integrated setting . . handicapped children will increase their social and language interaction ... [and also] can be taught to play with nonhandicapped chilgren either in a parallel or asso-
ciative manner.

He suggests also that integrating the severely and moderately handicapped into the normal environment allows them the same rights and privileges their normal peers have. He avers that such exposure to the normal environment will promote the development of the handicapped child. Some of the problems with integrating severely handicapped

15 Wolfensberger, N. "The Principle of Normalization in Human Services," Toronto, Canada, National Institute on Mental Retardation, Chapter 9, p. 124.

16 wolfensberger, p. 127.

17 Fredricks, B. et al. "Integrating the Moderately and Severely Handicapped Preschool Child Into a Normal Daycare Setting," Early Intervention and the Integration of Handicapped and Non-Handicapped Children, "Ed." Michael Guralnick" University Park Press, Baltimore, 1978, p. 203. 
children stem from their complex needs and the vast range of differences that can exist between each child. In his study, Fredricks learned that the children did indeed benefit by integration but that, in order to facilitate this change and expect success, the staff of the daycare center must receive special training.

The introduction of non-handicapped peers into the special child's environment has a marked positive effect on the social interaction and involvement in play of the handicapped child (Devaney, Guralnick, Rubin, 1974). Increased frequency and complexity of verbalizations is observed, as well as a higher quality of play, as a result of the modeling and interaction that occurs in this setting. The nonhandicapped child serves as agent of change and reinforcement (Guralnick, 1976). Direct reinforcement by peers becomes a potent form of social influence during childhood. It is not the mere presence of the non-handicapped child in the environment, but the way in which interaction among children is encouraged and guided, that leads to positive changes.

These processes of change established, one must then confront the problem of introducing the agents of change, for the peer is only one kind of agent, while the staff are another. Thus arises the important issue of staff development. Daycare center staff as well as special educators must be trained.

To become skilled in relevant programming we must re-learn our child development sequence in great detail. We must be aware of what stage a child is 
at now, and how to help this child move to the next stage of development.

Many early childhood workers and professionals lack the skills and training necessary to work with special needs children, and special educators are not trained in early childhood development. A fact that contributes largely to the problem is that daycare workers have no access to inservice or training for the special needs child.

Buescher's (1982) Immersion Learning Project is an inservice model that provides intensive and effective training to daycare/early childhood staff. Its focus is on the culturally and linguistically different handicapped child, but its approach can be applied to the training of staff for a variety of special needs children. Its overall goal is to increase the knowledge and expertise of staff in centers in the Detroit area whose only obstacle to accepting special children was their own lack of specialized provisions and training. The three kinds of activities incorporated in the first year of the project were: 1) learning/exchange sessions, 2) technical assistance and 3) development of usable products for the client. An important point to consider in training daycare staff is that they may have learning methods that necessitate different strategies than those typically used with teachers, nurses, etc.

Some of the literature regarding daycare and the handicapped was focused more specifically on the preschool environment exclusively for the handicapped. Thus, daycare, per se, was not addressed, but the

$18_{\text {Buehler, Diane and others, Daycare: Children with Special }}$ Needs, Dept. of National Health and Welfare, Ottowa, Canada, 1975, p. 54 . 
programs, either observed or designed by the authors, provide a good deal of useful information with regard to the kind of setting, staff needs, etc., that can enhance daycare services for the handicapped. Buehler (1975) discusses the qualities of a good early childhood service for the handicapped. Among these qualities are: 1) readily available to the user; 2) approachable staff and administration with mutual respect between staff and families, with the use of everyday language, as opposed to the jargon of trade, for communication;

3) cohesion in a complementary make-up of staff and program; 4) continuity; 5) individualized programs that offer alternatives to meet varied needs of children and their families; 6 ) intensive in content so that a variety of techniques are being utilized and 7) relevance, so that concrete experiences are provided to help the children learn.

Thelon (1978) suggests that a delivery of services to young handicapped children include a system to gather and disseminate information regarding services that are provided, and regarding the needs of preschool children. Donohue (1971), in evaluating preschool/daycare services in Maryland, says that a good center for the handicapped will coordinate all the services by health, education and social agencies to provide continuity so that all the necessary programs and evaluations are provided to the child and family. He further describes a successful strategy in which the important parent participation that is vital to working with the special needs child is implemented through a public health nurse. This nurse's contact with the homes and families keeps center and families in touch and involved. Representation on the board of the daycare center, says Donohue, is another strategy for parent 
involvement in process and policy. This also puts the center in closer contact with parent needs.

The Technical Assistance Development System (TADS) (Suarez et al., 1981) provides comprehensive assistance to personnel implementing programs for preschool handicapped. It is part of the National Handicapped Children's Early Education Project [HCEEP]) and assists demonstration programs in accomplishing their goals more effectively. It seeks the various methods for providing technical assistance and includes: 1) on-site visitations from consultants, 2) telephone conferences with consultants and 3) self-administered program packets with necessary materials.

Sande's (1980) Non-categorical Early Childhood Program for Handicapped Children (NECP) was established to provide a comprehensive program for mild to moderate young handicapped children (2 to 8 years). Its aim was to bring together all the services inherent in the special programs with all the services inherent in the early childhood programs, thereby providing a rich and exciting new concept in special education. In addressing the mainstream process, Sande determines that this could be manifested in any number of ways, from special services provided for part of the day to brief consults on a periodic basis.

Kurvant (1976) treats as her subject the physical environment and how to make the necessary changes for handicapped individuals within the center setting. The author defines three categories of handicap-mentally retarded, physically handicapped and emotionally disturbed-ranging them in rates from minimal to severe and profound. Although inclusion of the handicapped into regular programs provides financial 
boons as well as social advantages, there are potential dangers that can inhibit this process and prevent success. To integrate before facilities and staff are properly prepared is one of those dangers. Such a setting would be ill able to meet the needs of special children. For the severe population this is a critical time, for unprepared staff and space could do a great disservice to the children rather than providing the desired advantages.

However, how prepared is the space in special programs? They are not set up to be all things to all children, and space and staff both must adapt to children's needs. In fact, these special settings are less able to meet the needs of young children than daycare centers that offer environments geared toward the young child, and that already have necessary materials such as sinks, toilets, tables and chairs.

Although they need special equipment such as ramps and wheelchairs to adapt the environment, these physical limitations should not be enough to keep special needs children out of regular programs. Besides, says Kurvant (1976), even the physically handicapped child who requires the most structural adaptation, can be brought into these programs once we have decided that such programs are desirable and they become priorities. Then it becomes a matter of meeting present needs by generating funds for space alteration, and where space alterations are prohibited more staff must be made available. Kurvant also suggests that training staff to deal with special needs children must also become a priority. The research on the young handicapped was aimed at two topics. One was the importance of integration of the handicapped and non-handicapped 
child. The second was the importance of daycare staff development through inservice training and technical assistance.

The research (Fredricks, 1978; Kurvant, 1976; Guralnick, 1976; Devoney, et al., 1976) shows that the benefits of integration are manifold and mutual, including increased language and verbalization skills for the handicapped; increased social interaction for both; development of peer relationships for both; accelerated development of the handicapped child; and tolerance and appreciation for each other.

Secondly, the literature (Buescher, 1982; Sauer, 1975, Suarez, 1981) points to the need for daycare staff development, particularly by way of support and training. The support required is in the form of technical assistance from the professional community and the community at large. It also can come from the use of outside consultants. In house, the centers themselves could organize on-going inservice education, intensive training through seminars, and even through grant development for the purpose of outside schooling for appropriate daycare employees. The daycare and the professional community must ever keep their eyes on mainstreaming as an achievable goal.

What do we want our children to become? What do we want our children to come to value? What do we want them to be able to feel, and see and hear and smell and touch?... What do we want them to understand about themselves and the world of nature and man? How do we want them to behave toward other human beings? ....1

19 Tuman, M. "Teaching in America," Saturday Review, 50; 1967, "qtd. in" Davis, Bette Joe and Jacquel ine Blackwell, "Humanistic Education and the Handicapped Child: Implications for Quality Day Care Programs." U.S. Dept. of Education, 1978, p. 13. 
Inasmuch as daycare centers seem the likely place to begin the process of integration of young handicapped children with their normal peers; and because there are already early childhood programs established, it is necessary to discover how many existing centers are willing to serve the moderately to severely handicapped child and begin the integration process. 
CHAPIER III

\section{PROCEDURES}

In order to poll the daycare centers in the Portland Metropolitan area it was necessary to obtain an updated list of all its existing daycare centers. The Child Care Coordinating Council (4C's) was contacted and, with their assistance, an updated (June 1985) list of daycare centers organized by counties was obtained. The counties included Multnomah, Washington, Clackamas, Clarke, Columbia, Yamhill and parts of Marion (north of Woodburn). In addition to the name, address and phone number of the centers, the list also included the director's name, the latest list revisions (ranging from May 1984 to June 1985), the minimum and maximum age of children served and the kind of special needs children served. There were 181 centers listed with the majority being in Multnomah County (92), Washington County (39) and Clackamas County (29). Of the 181 centers, information from 38, or 20 percent, had been updated in 1984, between May and October.

The research instrument used in this study was a short questionnaire (Figure 1) consisting of questions eliciting pertinent information about the center. The information requested included number of children served, ages of children served, fees charged and questions regarding services for special needs children at the center, i.e., the type of special need served, the requirements, if any, to attend and 
the reason for not accepting special needs children where such explanation was applicable.

This questionnaire, along with a cover letter (Figure 2) explaining the intent of the research project and a self-addressed, stamped envelope was mailed to each of the 181 centers.

Within two weeks 94 questionnaires were returned. This represented 50 percent of the population polled. Phone calls were then made to the centers that had not responded to obtain the requested information, but this effort proved fruitless for a number of reasons: 1) most directors/staff were not available to answer questions or 2) if they were available they asked for another questionnaire to fill out as they were very busy with children during operating hours and could not take the time to answer questions over the phone. Therefore, a second mailing was prepared and sent to all the centers that had not responded to the first questionnaire. Eighty-two centers received a second mailing and 23 were returned within two weeks. Four centers have since closed due to financial difficulties and one letter was returned unopened because the addressee no longer existed. That left 176 centers within the population.

The data were compiled on worksheets in such a fashion as to afford the researcher a convenient view of information regarding:

1. The total number of children served by daycare centers.

2. The minimum and maximum ages of children served in centers in the Metro area.

3. The average fees charged by centers.

4. The number of centers serving handicapped children. 
QUESTIONNAIRE

1. Name of center:

2. Director:

3. Age of children served: Minimm age Maximum age

4. Number of children at center (full capacity):

5. Are there any requirements to attend? (i.e., toilet trained, etc.)

6. Number of staff: full-time part-time

7. Fee for services: per week per month

8. Do you serve children with special needs? YES NO If the answer to \#8 is YES, please continue with questions 9 to 14 . If the answer to $\# 8$ is NO, please go to question 13 and continue.

9. Type of special needs served: (check all boxes that apply)

Type of Special Need

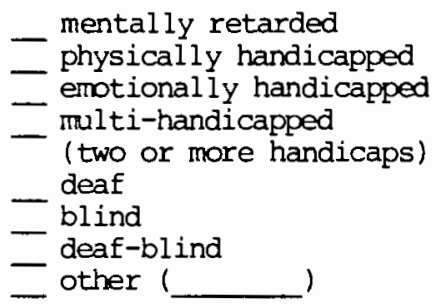

Degree of Severity

$$
\begin{aligned}
& \text { _mildly _ moderately _- severely } \\
& \text { - mildly - moderately - severely } \\
& \text { - mildly - moderately - severely } \\
& \text { - mildly _ moderately _ severely } \\
& \text { _ mildly _ moderately _ severely } \\
& \text { - mildly - moderately - severely } \\
& \text { - mildly - moderately - severely } \\
& \text { - mildly _ moderately _ severely }
\end{aligned}
$$

10. Do you have any children with special needs presently enrolled? YES NO

11. Number of special needs children enrolled.

12. Are there any special requirements for children with special needs? Please list.

13. If your answer to question \#8 is No, please check reasons that apply:

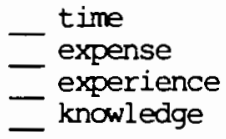

14. Do you provide a kindergarten program? YES

$$
\begin{aligned}
& \text { - staffing } \\
& \text { - support } \\
& \text { - other ( }
\end{aligned}
$$


July 15, 1985

Dear

I am a Portland State University graduate student in Education. I do doing a research project about daycare for children with special needs and I am conducting a survey of all daycare centers in the Portland Metro area. I need a few short minutes of your time to find out some pertinent information regarding services for children with special needs. I will be compiling this information and would be glad to send you the results if you so indicate.

Enclosed is a questionnaire and self-addressed stamped envelope. Please fill in the questionnaire and return it to me in the envelope provided within two weeks.

Thank you for your time.

$$
\text { Sincerely, }
$$

Jackie Freni-Rothschild

Figure 2. Letter 
5. The type of handicaps centers are willing to serve.

6. The degrees of handicap these centers would serve.

7. The requirements for acceptance of special needs children.

8. The total number of special needs children currently served.

9. The number of centers not serving special needs children.

10. The reasons for not serving special needs children.

11. The number of centers providing a kindergarten program. Upon examination of the data of the 114 questionnaires returned, it was found that four centers had closed, and nine centers were actually full-time schools and operation of their daycare centers was attendant to their school function. Since these nine centers were offering alternative education as well as daycare, and since the children enrolled in these daycare environments must also be enrolled in the schools, the data from these nine were excluded from the results. In addition, there are three daycare centers with unique characteristics that set them apart from the others. These are centers established under the auspices of an employer for the provision of daycare to employees' children. One of these is a local hospital whose daycare center serves children of employees first, and then offers any extra space to the public. The admission of special needs children is limited by the usual application of request conditions, such as type of handicap, and degree of severity. The second such organization is a community college. Their daycare program is aimed at the children of staff, faculty and students. Again, any additional spaces are offered to the general public. They, too, have specific criteria when it comes to serving the handicapped. Furthermore, they are limited by the fact 
that their schedule of openings and closings is governed by the school term schedule. The third organization is a Jewish Community Center, which serves only its own members. However, this center has no limitations on the type or degree of handicap, and accepts all children of its served population. The data from these groups was included in the overall study. This then afforded the researcher 101 daycare center studies from which to extract the data necessary for this project. Among the centers polled, there are nearly 7,000 children being served. However, a very small number of them are considered special needs children. The research instrument was designed to learn not only how many handicapped children are being served, but also to learn what kinds of handicaps are addressed and what degree of severity of handicap the centers are willing to serve. Furthermore, it was designed to determine the kinds of requirements or conditions that are prerequisite to the admission of the handicapped child in the particular program. 


\section{CHAPTER IV}

\section{RESULTS}

\section{Number of Daycare Centers Accepting Handicapped Children}

In the 101 centers polled, there are 6,741 children being served. Of this population 88 children, or 1.3 percent, are considered special needs children. In Table $I$ is seen the number of centers that will accept special needs children and the types of handicaps served in the centers. 20 These handicaps include:

Mentally retarded (MR) - delayed development by at least one year Physically handicapped (PH) - a physical impairment ranging from spinal bifida to cerebral palsy to quadrapelegia Emotionally handicapped (EH) - delayed social development often characterized by severe behavior problems Multihandicapped (MH) - delayed in at least two areas of development (including social, motor, and language)

Deaf - hearing impaired

Blind - visually impaired

Deaf/Blind - hearing and vision impaired to varying degrees Other - many uncommon disorders marked by above listed characteristics such as autism

${ }^{20}$ Figures reflect that some centers serve more than one degree of severity. 
The levels of severity of handicap accepted by various centers have been categorized as mild, moderate, and severe. ${ }^{21}$

\section{TABLE I}

THE NUMBER OF CENTERS THAT ACCEPT SPECIAL NEEDS CHILDREN AND THE DEGREE OF SEVERITY THEY WILL SERVE

\begin{tabular}{|c|c|c|c|c|}
\hline \multirow{2}{*}{$\begin{array}{l}\text { Type of } \\
\text { Handicap }\end{array}$} & \multirow{2}{*}{$\begin{array}{l}\text { Total No. } \\
\text { of centers }\end{array}$} & \multicolumn{3}{|c|}{ Degrees of Severity } \\
\hline & & Mild & Moderate & Severe \\
\hline MR & 36 & 31 & 14 & 3 \\
\hline $\mathrm{PH}$ & 42 & 32 & 18 & 4 \\
\hline $\mathrm{EH}$ & 36 & 31 & 11 & 0 \\
\hline MH & 18 & 10 & 12 & 1 \\
\hline DEAF & 26 & 18 & 8 & 7 \\
\hline BLIND & 13 & 8 & 4 & 3 \\
\hline $\begin{array}{l}\text { DEAF/ } \\
\text { BLIND }\end{array}$ & 7 & 3 & 2 & 1 \\
\hline OTHER & 15 & 9 & 4 & 2 \\
\hline DID NOT & & & & \\
\hline STATE & 7 & $\underline{0}$ & $\underline{0}$ & $\underline{0}$ \\
\hline TOTALS & 60 & 50 & 38 & 14 \\
\hline
\end{tabular}

There are 60 respondents that serve handicapped children, but their definition of handicapped is limited. Among these centers the most commonly accepted handicap condition is physically handicapped, with 42 of the 60 centers stating that they accept them. Only 36 centers accept as students the mentally retarded and the emotionally

$21^{2}$ is worthwhile to note that the centers polled did not share a common definition of mild, moderate and severe. 
handicapped. The hearing impaired child is allowed into 26 of these centers and a mere 18 of these centers is prepared to accept the multihandicapped child. Seven centers responded generically in that they stated they accepted special needs children, but failed to specify what "special needs" they included. The further generic category known as "other" special needs provided some useful information. These other special needs are: 1) food allergies, served by two centers; 2) speech impairment, served by three centers; 3) heart monitor, served by one center; 4) non-English speaking, served by two centers; 5) diabetes, served by one center; 6) low income, served by one center and 7) abused/neglected, served by one center. This last category could be cross-defined as emotionally handicapped as well.

of the 42 centers that said they accepted physically handicapped children, 32 were limited to the mildly handicapped, 18 served the mildly and moderately handicapped, and four were engaged in serving severely physically handicapped children.

These figures indicate that some centers accept children with varying handicapping conditions ranging from mild.all the way to severe, since the centers from which these data emanate total 42 in number. However, for the mentally retarded and emotionally handicapped, the figures indicate that only the mildest forms of these conditions are likely to be served. As the degree of severity increases, the number of service resources decreases. For the severely mentally retarded child there are four centers available, and for the severely emotionally handicapped there are none. The number of centers accepting children with severe handicaps is small compared to the number 
of centers which serve the mildly or moderately handicapped. Of the 60 centers that are willing to serve special needs children, 40 have these children enrolled presently. Of these 40 centers, 38 will serve some kind of moderately handicapped child, and only 14 will serve some form of what they deem to be severely handicapped. These include the physically handicapped, the hearing impaired, the speech and language impaired, and the non-English speaking child.

\section{Conditions for Accepting Handicapped Children}

What exactly is meant by the terms mild, moderate and severe when used to describe handicapping conditions? The definitions depend variously on the centers' own arbitrary standards. For example, one center may deem a Down's Syndrome child severely handicapped, whereas another center may consider a speech and language impaired child severely handicapped. Again, while one center may consider a vision impaired child too severe for acceptance, another center may attempt to mainstream a severely physically impaired child. Hence, the definition of these terms are implicit in the criteria of acceptance of the various daycare centers. In Table II, these conditions and criteria are addressed, as are the degrees of severity that these centers are prepared to accept. (Each figure represents the number of centers prepared to serve that handicapping condition.)

The most frequently stated requirement in Table II for the admission of special needs children into the daycare center is that they fit into the regular program and not require extra attention or help that distracts staff from meeting the needs of the other children. It is important that the special needs child not need a one to one relation- 
ship with a staff member, because such an arrangement is too costly for the center. Fourteen centers require that the special needs children be able to participate, unassisted, in the regular program and all 14 centers accept the mildly and moderately handicapped.

\section{TABLE II}

CONDITIONS FOR ACCEPTING SPECIAL NEEDS

CHILDREN AND DEGREES OF SEVERITY SERVED

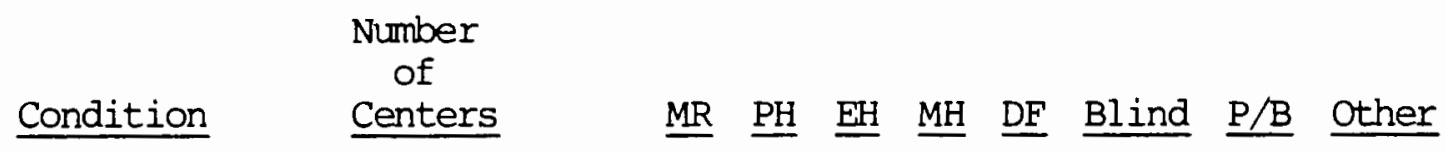

1. Able to Handle Regular Program

(no $1: 1$ ratio)

$\begin{array}{lcccccc} & \text { mild } & 9 & 9 & 8 & 2 & 4 \\ \text { mod. } & 4 & 5 & 4 & & 2 \\ \text { sev. } & 1 & & & & 1\end{array}$

2. Staff Able to Meet Needs of

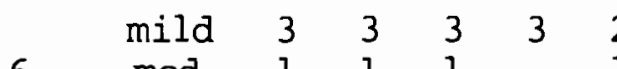

Childs

6 mod. 1 1 1101

3. More Money Charged if requires more time/staff

$\begin{array}{cccccc} & \text { mild } & 2 & 2 & 2 & 1 \\ \text { mod. } & 1 & 1 & 2 & 1 \\ \text { sev. } & & & 1 & \end{array}$

4. Support/ Training for Staff

3

5. Parental

Support and Cooperation

$\begin{array}{lrllllll}6 & \text { mild } & 3 & 2 & 3 & 1 & 2 & 1 \\ \text { mod. } & & & & 2 & & 2\end{array}$

6. Other

$\operatorname{mild} \quad 1 \quad 1 \quad 2$

mod.

sev.

\section{. Other}

7. None

$8 \quad \operatorname{mild} 2$

$\begin{array}{lllllllll}\bmod . & 3 & 5 & 3 & 1 & 2 & 2 & 1 & 1 \\ \operatorname{sev} & 2 & 2 & 1 & 4 & 2 & 1 & 1 & 2\end{array}$

8. None Stated

$12 \begin{array}{llllllll}\operatorname{mild} & 8 & 8 & 7 & 4 & 4 & 3 & 2 \\ \bmod . & 3 & 4 & 4 & 4 & 3 & 3 & \\ \text { sev. } & 2 & 3 & 2 & 2 & 2 & 2 & \end{array}$


Two of the above 14 centers accept the severely handicapped child. One of these centers refers to non-English speaking children as severely handicapped. The other center refers to a hard-of-hearing child as severely handicapped. Five centers accept only special needs children whose handicaps they consider mild. Seven centers accept the mildly to moderately handicapped child, but among these seven are a variety of determing factors. For example, one center may accept a mildly mentally retarded child, a moderately physically handicapped child, and a moderately hearing impaired child. Another center's criteria might include an entirely new and unrelated mix of handicaps without weighing equally the types of handicaps they are serving.

Parental cooperation and support is a requirement for attendance in six centers. They will work with the special needs child if the parents educate staff and/or provide needed materials and equipment. However, these centers only serve the mild range in six types of handicaps and the moderate range in two types of handicaps. Two centers serve only the mildly handicapped and four serve the mildly and moderately handicapped.

Six centers will accept special needs children if the present staff can meet the needs of the child adequately, and if they believe they can do a proper job. Again, only the mild to moderate range is addressed. The one exception is a child with spinal bifida who is considered severely physically handicapped.

Eight centers offer no specific requirements for accepting handicapped children, but here again, four of these centers are able to serve only the mild to moderate range. Of the four that claim they are willing 
to serve the severely handicapped, one center operates in a hospital setting and will accept the severely handicapped; one is a Jewish community center and takes member's children regardless of handicap or degree of severity; one currently has a severely vision impaired child enrolled and states that this child takes alot of staff time; and one is a small Christian daycare center that was unavailable for comments and has no special needs children presently enrolled.

Twelve centers failed to answer the question regarding requirements, but they stated that they would work with mildly to moderately handicapped children. Three of these 12 stated they are willing to serve severely handicapped children. Of these, one is on a college campus and to date has served all special needs children that have applied. Another daycare center has a staff that are experienced with such children and have served a number of young handicapped children. The third center is a small regular center and could not be reached for comment due to vacation.

In the condition titled "other" the various reasons stated for accepting special needs children were: 1) that applicants be professionally diagnosed; 2) that individual children be evaluated case by case upon request for admission; 3) that children be accepted only on a trial basis allowing staff to gain experience with the handicapped child; 4) director's discretion and 5) only those who require special food preparations. Again, it is primarily the mildly handicapped child that is being served here. Only one center works with all types and degrees of handicaps and this is the one served by Headstart, with its accompanying support and funding. Four centers will serve only the 
mild range and two will serve only one kind of moderate condition. Four will serve the severely handicapped population, but, of these, one center refers to speech and language disorder as a severe handicap, one has had prior experience with severely handicapped children and one is a Headstart program.

Types of Handicaps Found in Centers

Of the 60 centers that stated they were willing to serve special needs children, nine centers did not state the kind of handicap and/or the degree of severity. Six of those nine centers, interestingly enough, have no special needs children enrolled, nor have any such children made application. Thus, they have not had the opportunity to serve this population, even though they claim they are willing to do so. One of the nine centers claimed that policy forbade them to reveal the kind or severity of handicap they accept, but went on to reveal that. they presently serve a vision impaired child. The other two centers divulged the kind of handicap they will serve, but not the severity of handicap and one of the centers serves primarily low-income families. There are 40 centers that currently have special needs children enrolled. The kinds of special needs children enrolled vary and, according to data gathered by phone calls and questionnaire, they are predominately in the mild to moderate range in degree of severity. The types of special needs children currently being served in 27 centers in the Portland Metropolitan area are listed in Table III. The children identified are from the 1.3 percent of the population being served. 
TABLE III

KINDS OF HANDICAPS CURRENTLY SERVED

IN DAYCARE CENTERS

Type of Handicap

MR/devel. delayed

$\mathrm{PH}$

MH

$\mathrm{EH}$

Hearing Impaired

Vision Impaired

Deaf/Blind

Other

Total (27 centers)

Total No. Being Served

(40 centers)
№. of Children

6

2

8

4

2

2

$\underline{17}$

54

88

Daycare Centers Not Serving the Handicapped

Forty-one centers (40 percent) do not serve special needs children. The array of reasons and the number of respondents are displayed in Table IV.

Most of the 41 centers stated more than one reason for not accepting special needs children. The reason most frequently given was staffing. Oregon state law requires a 1:10 staffing ratio with children $21 / 2$ to 12 years, and 1:4 staffing ratio with children under $21 / 2$ years old. As staff salaries are one of the biggest expenses in operating a daycare center, the 11 centers giving expense as a reason could also be concerned with staffing ratios. The large numbers next to 
"experience" (22) and "knowledge" (20) also bear some relevance to the staffing issue. Low paid positions do not attract highly skilled personnel and centers also lack the resources needed to upgrade the skills of present employees.

In the "other" category, only two reasons were expressed. One was that the daycare center's environment was not equipped to meet the needs of the special child, and the other was that no special needs children had ever applied. One center expressed no interest at all in serving special needs children.

TABLE IV

REASONS FOR NOT ACCEPTING SPECIAL NEEDS CHILDREN INIO DAYCARE CENTERS

$\underline{\text { Reason }}$

Time

Expense

Experience

Knowledge

Staffing

Support

Other

None Stated
No. of Responses

8

11

22

20

29

6

14

3

Age of Children in Daycare Centers

The average minimum age for children in daycare is $21 / 2$ years old. Fifty percent of the centers accept children at this minimum age. Forty-six percent of the centers serve infants 6 weeks to $21 / 2$ years 
of age, with 31 percent of this group taking infants at 6 weeks old. The average maximum age is 12 years old, with 35 percent of the centers accepting children through this age, while 23 percent of the centers take children only through the age of six. Figures 3 and 4 display the minimum and maximum ages of children served in daycare centers.

Of the 31 centers serving infants at 6 weeks, 21 of these centers are prepared to serve special needs children. Only 24 of the 50 centers that accept children at $21 / 2$ will accept special needs children. Of the 23 centers that take children through the age of six, 15 are willing to take special needs children. Table $\mathrm{V}$ displays this data.

\section{TABLE V}

NUMBER OF CENTERS THAT SERVE SPECIAL

NEEEDS CHILDREN BY AGE

\begin{tabular}{cccc} 
Min./Max. Age & No. of Centers & Serves "Special Needs" Children \\
\cline { 3 - 3 } 6 weeks & 31 & 21 & Yes \\
6 months & 2 & 2 & 10 \\
12 months & 8 & 8 & 0 \\
18 months & 3 & 3 & 0 \\
2 years & 3 & 2 & 0 \\
2 1/2 years & 50 & 24 & 1 \\
3 years & 3 & 1 & 26 \\
5 years & 7 & 5 & 2 \\
6 years & 23 & 15 & 2
\end{tabular}




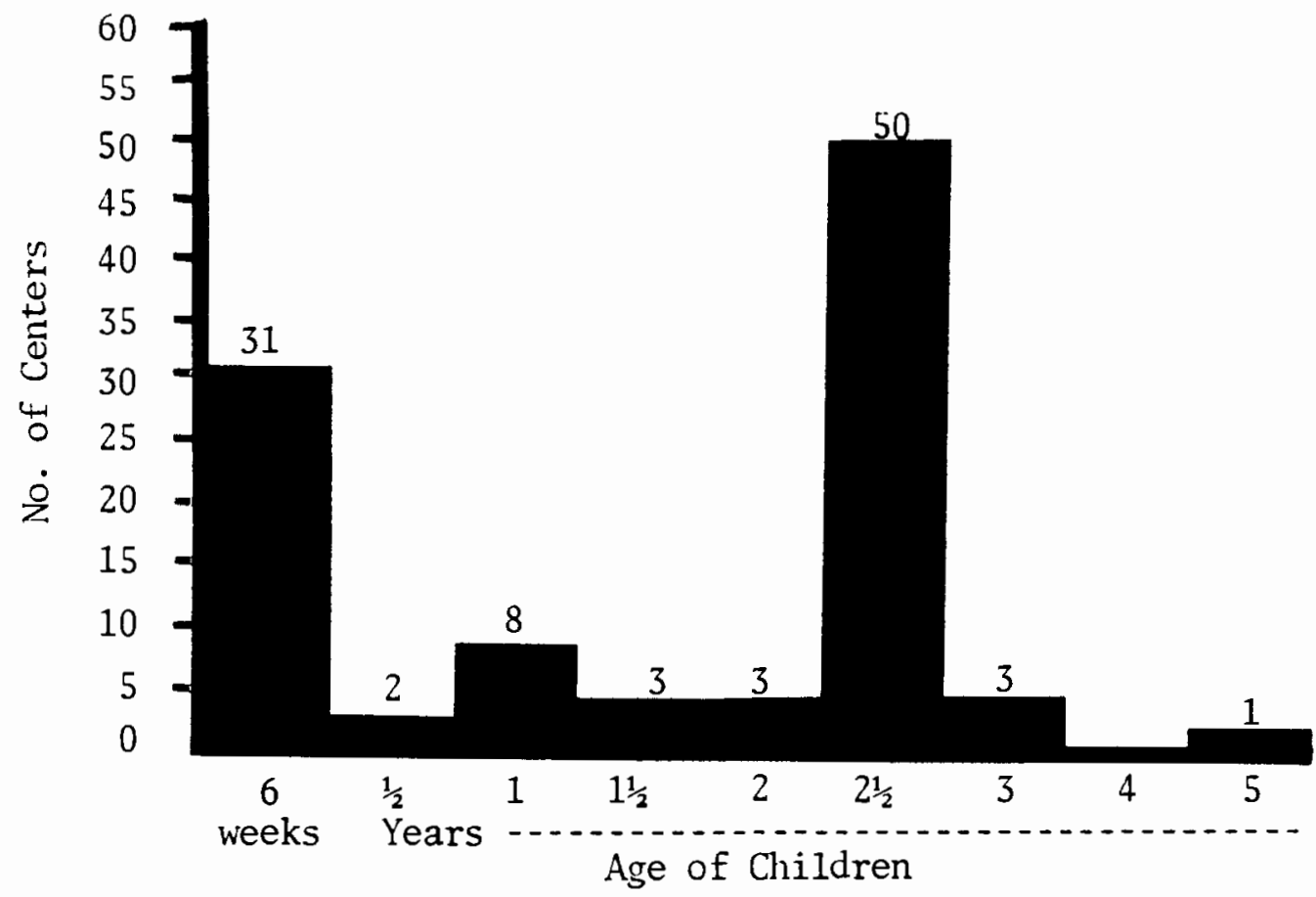

Figure 3. Minimum ages of children in daycare centers.

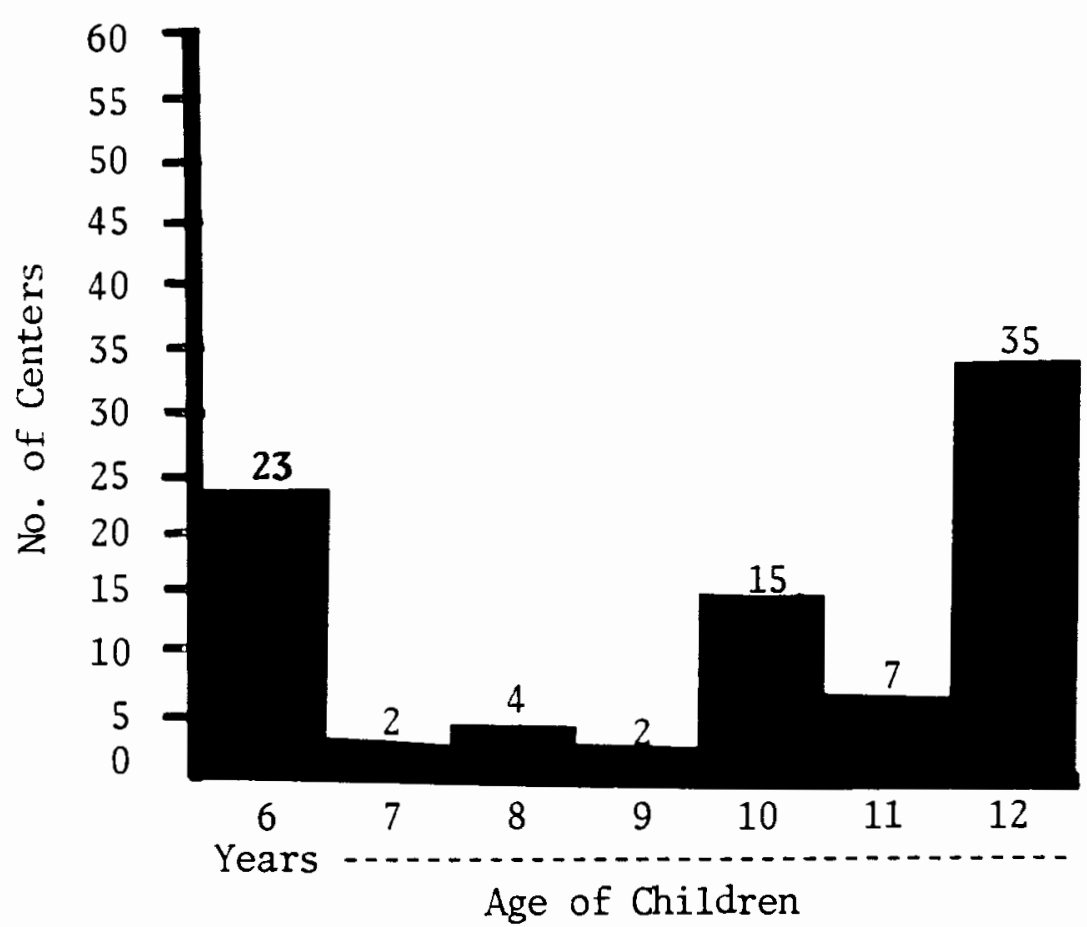

Figure 4. Maximum ages of children in daycare centers. 
Kindergarten Programs in Daycare Centers

Of the 101 centers polled, 65 centers (or 62 percent) provide a kindergarten program. Of these 65 centers, 40 will serve special needs children and 11 of these will serve severe special needs children. These severe handicaps include hearing impaired (7), physically handicapped (4), mentally retarded (4), multihandicapped (6), vision impaired (3), and non-English speaking (1).22 one of the centers that serves the severely handicapped has a large staff (27 full-time employees). Another one of these centers is a Headstart program and a third center is based in a hospital setting. One center takes only non-English speaking children and another center has never had the opportunity to serve the handicapped child, but expresses the willingness to do so. Twenty-four centers with kindergarten programs do not accept the handicapped.

${ }^{22}$ Figures reflect that some centers serve more than one type of handicap. 


\section{CHAPTER V}

\section{CONCLUSIONS AND DISCUSSION}

The purpose of this study is to discover how many handicapped children, particularly moderately to severely handicapped children, are served in daycare centers in the Portland Metropolitan area. The handicaps to which this study is more particularly addressed are the mentally retarded, physically handicapped, emotionally handicapped, hearing impaired, and vision impaired. The terms "special needs" and "handicapped" are used interchangeably.

There are 88 special needs children enrolled in the 101 daycare centers participating in this study. The figure 88 represents 1.3 percent of the total number of children enrolled in the centers. Because the number of young handicapped children (0-6 years) in the general population is not known, the figure 1.3 percent cannot be compared to the population overall.

The 88 children are enrolled in 40 centers in the city environs. Another 20 centers indicated that they were prepared to serve special needs children, but at this time have none enrolled.

The term "special needs children" is interpreted in as many ways as there are daycare centers to serve them. The term is used variously to describe physically handicapped, developmentally delayed, and hearing impaired, as well as children with food allergies and special diets. Forty-two centers accept physically handicapped children; 36 accept mentally retarded and emotionally handicapped children; 
with hearing impaired, "other" handicaps, multihandicapped and vision impaired following respectively (see Table I). The "other" handicap category includes such conditions as speech and language disorder, nonEnglish speaking, and special diets, to name a few.

Of the 13 centers that accept "other" handicapped children, 10 are also able to serve some of the more common types of special needs children including physically handicapped, mentally retarded, and emotionally disturbed. Most of the centers that indicate a willingness to serve the handicapped are accepting only the mildly handicapped, such as a child with cerebral palsy who ambulates more slowly than peers, but is independent in all other regards; or a child who is delayed in speech and language development. Even those centers that expressed a readiness to serve a special needs child indicate a strong bias for the least involved child.

Fifty centers claim to serve the mildly handicapped. Of the 50 centers, 64 percent will accommodate the physically handicapped (PH); 62 percent will serve the mentally retarded (MR) and/or emotionally handicapped $(E H) ; 36$ percent will serve the hearing impaired; and under 20 percent accept the multihandicapped (MH) and vision impaired. Thirty-eight centers will accept the moderately handicapped and, again, it is the physically handicapped ( 47 percent) that is most widely accepted, with mentally retarded, multihandicapped, and emotionally disturbed following respectively. The greater the handicap the fewer the resources available. 
TABLE VI

PERCENT OF CENTERS THAT ACCEPT MIID, MODERATE, AND SEVERE HANDICAPPED CHILDREN

Handicap $\frac{\text { Percentage of }}{\text { Mild }} \frac{\text { Centers }}{\text { Moderate }}$ that $\frac{\text { Accept }}{\underline{\text { Severe }}}$

MR

62

37

21

$\mathrm{PH}$

64

47

28

$\mathrm{EH}$

62

29

0

$M$

20

31

7

Deaf

36

21

50

Blind

16

10

21

Deaf/Blind

6

5

7

Other

18

10

14

Total No. of Centers 50

38

14

Only 14 centers are prepared to accept children with severe handicaps (see Table VI). Three of these 14 are unusual enough to be worth mentioning. One of these is in a hospital setting and designed to accommodate the severely physically handicapped. Another is in a Jewish community center and accepts all of its members' children. The third is a center served by Headstart, which must serve handicapped in their population, and which receives funds for this purpose. This leaves 11 centers that accept severely handicapped children from the general population, and whose definitions of severely handicapped vary from center to center. 


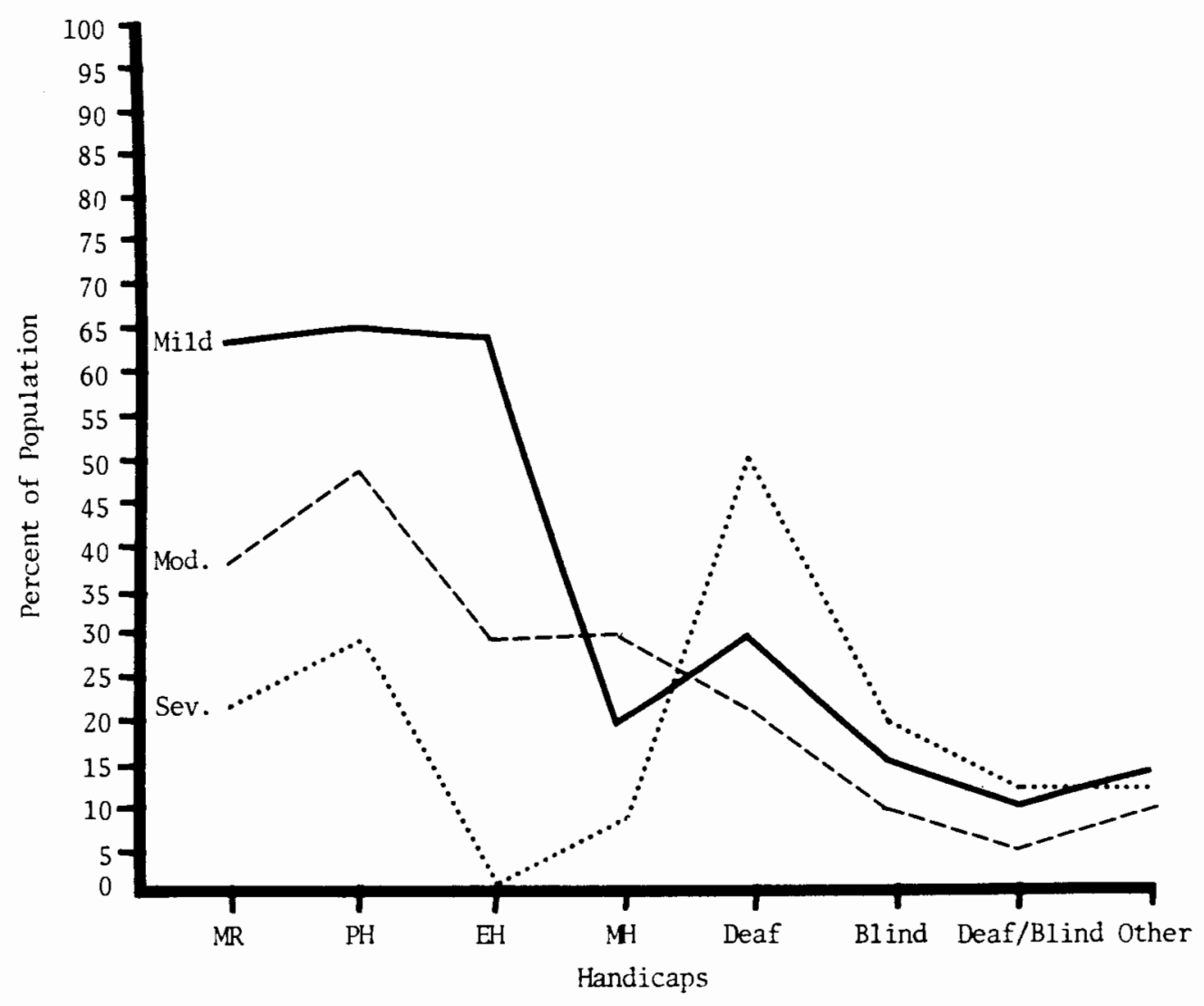

Figure 5. Comparison of the percentage of population of each handicap for each degree of severity. 
The information gathered in the questionnaire produced no common definition of degrees of severity (mild, moderate, severe). It became obvious in reviewing the data that each center had its own way of defining severe. This study was designed to identify services available to children labeled moderately to severely multihandicapped, whose conditions are typified by delayed development in one or more areas (e.g. language, social, motor, self help); and whose handicaps are permanent and irremediable. Given the paucity of services available to the severely handicapped child, had this study addressed only questions regarding that population, the resulting data would have been slim indeed. The information gathered shows plainly that these children remain virtually overlooked in the areas of early childhood education and daycare.

Once the questionnaires were returned and the data compiled, selected centers were then contacted by phone and asked what kinds of handicaps, specifically, were currently being served. Nine centers had provided specific details about the special needs children they were serving, but 32 had not. These 32 stated only that they had a certain number of special needs children enrolled. As a result of the followup phone calls, it was learned that some of the special needs children that had been enrolled in the centers during the summer months were no longer attending in the fall. The first set of questionnaires were sent in July, the second in August, but by September's follow-up calls, many children had changed daycare situations.

It became obvious that centers have summer programs and school year programs. This factor could have influenced the answers to the 
inquiry regarding the number of children enrolled at the centers because the questionnaires were sent out during the summer months.

One half of the centers (50) begin serving children at $21 / 2$ years old, and 31 centers take children at six weeks old (see Figure 3). Twenty-three centers serve children through the age of six years, and 15 centers serve children through 10 years old (see Figure 4).

Of these various age groups the largest (numbering 14) serves children $21 / 2$ to 12 years; 10 serve ages $21 / 2$ through 6 years. The special needs child would fall into any age group, and although this study focused on the early childhood group (0-6 years), the special needs children served were all ages. In a follow-up phone call to one respondent center it was discovered that the severely handicapped child they served was 10 years old, spent the day in special classes and was transported to the daycare center in the afternoon. This child was then integrated with younger children.

Through the answers on the questionnaires it became clear that special needs children are denied access to daycare centers for a variety of reasons: 1) staffing is already stretched to an unrealistic ratio; 2) centers fear the potentially higher expenses of meeting special needs; 3) inadequate facilities are cited as a barrier and 4) lack of expertise in caring for and teaching this kind of child. A center that is currently serving a severely handicapped blind child stated on the questionnaire that this child required extra one-to-one time with staff, an important concern for a center with a limited staffing pattern. Another center, it was discovered in a phone call, 
TABLE VII

NUMBER OF CENTERS BY AGE RANGE SERVED

$\begin{array}{lrrr}\text { Age Range } & \text { No. of Centers } & \text { Age Range } \\ 6 \text { weeks }-2 & 1 & 2 & 21 / 2-5 \\ 6 \text { weeks }-5 & 1 & 10 & 21 / 2-6 \\ 6 \text { weeks }-6 & 8 & 2 & 21 / 2-7 \\ 6 \text { weeks }-9 & 2 & 3 & 21 / 2-8 \\ 6 \text { weeks - 10 } & 4 & 0 & 21 / 2-9 \\ 6 \text { weeks - 11 } & 2 & 11 & 21 / 2-10 \\ 6 \text { weeks - } 12 & 10 & 4 & 21 / 2-11 \\ 6 \text { weeks - } 13 & 1 & 14 & 21 / 2-12 \\ 6 \text { weeks - } 14 & 2 & 2 & 21 / 2-14\end{array}$

reversed its policy regarding enrollment of handicapped individuals after having served them, because their present staffing ratios no longer allowed them to meet equally the needs of all their wards.

Not only are handicapped children denied access in many instances, but their plight is exacerbated by the uneven quality of the staff members themselves. The low standard of pay among daycare centers makes it difficult for them to attract experienced and skilled personnel. Furthermore, competent personnel seeking career advancement quickly abandon the daycare field.

How are the centers that accept severely handicapped children meeting the needs of these children? Although this question was not a part of the original research instrument, some centers provided unsolicited data in this regard. In follow-up phone calls this line of 
inquiry was further developed. It was learned that the mildly handicapped are integrated into the existing population of the center. A few centers permit a moderately/severely handicapped child to be grouped with younger children where staffing ratios are richer. Three centers in Portland stated on the questionnaire that they will accept special needs children if the center is assured outside support. The aforementioned arrangements readily lend themselves to the concept of incorporating daycare centers into the existing education system. Daycare centers focus on early childhood development and have experience serving a large population. Special classes for the handicapped focus on serving the severely handicapped child. It may be necessary to develop a model that combines the disciplines of early childhood with special education. School districts need to look beyond boundaries and include the daycare center as a viable link in the developmental chain. The daycare centers are fertile grounds for inservice education and technical assistance in gaining the skills needed to work with handicapped children. The TADS program (Suarez, et al. 1981) demonstrated that daycare centers want to be redefined in the world of education.

Sixty-five of the centers in Portland provide a kindergarten program, but few accept the special needs child. Preschool classes for the handicapped served 1,244 children in Oregon in 1983-1984.23 If the staff of these special classes could work with the early childhood personnel of the daycare centers, the exchange of information and Education of the Handicapped Act. U.S. Dept. of Education, 1985. 
development of new skills would certainly be a benefit to all the children.

Although no attempt has been made here to measure the quality of the daycare center services provided, it would be worthwhile to evaluate daycare programs in terms of facilities, staff, materials and other resources. In such an inquiry might be sought a definition of a quality early childhood program and a definition of a quality program for the young special needs child. Furthermore, it could be ascertained whether the two are differently defined or are, in fact, one and the same.

The study operates under the assumption that the centers could provide integration of special needs and normal children and that integration would be considered the desirable policy. Integration teaches tolerance and imbues the children with a sense of responsibility for each other. Sande (1980) has developed a preschool program for the handicapped, the focus of which is integration of special children with their normal peers. The goal is to unite general education and special education programs so that children in both programs can benefit from the wide range of services, resources, and materials. There is the further advantage of positive peer models that occurs in the daily routine.

Kurantz (1976) suggests that modification of daycare facilities is the first order of business and must be done to accommodate the handicapped in the daycare center environment.

What does the future hold for young special needs children? Will the daycare centers be prepared to accept the moderately to severely 
handicapped child along with his normal peers? What conditions or inducements must exist in order for such integration to begin? will the centers be inclined to extend their services to the severely handicapped if they have more money? More staff? Better facilities?

Broader skills? It is only a matter of time until these questions will demand answers. The marriage of early childhood education and special needs daycare and education is a timely concept that offers limitless opportunities for exploration, learning and development of both the education and daycare professional and the child. 


\section{REFERENCES}

Buehler, Diane and others. Daycare: Children with Special Needs. Dept. of National Health and Welfare. Ottawa, Canada, 1975. Buescher, Thomas. Immersion Learning Project: Final Report Inservice Training Models for Preschool Programs for Handicap and At-Risk Children. Office of Special Education and Rehabilitation, Washington, DC, August 1982.

Child Care Coordinating Council, 1110 S.E. Alder St., Portland, Oregon. City Club of Portland. Report on Child Care Needs of working Parents in the Portland Metro Area. 46, Vol. 65 March 1983.

Davis, Bette Joe and Jacquel ine Blackwell. Humanistic Education and the Handicapped Child: Implications for Quality Day Care Programs. U.S. Dept. of Education. 1978.

Devolck, I. "The Preschool Child Goes to School: A Special Kindergarten Program in the Netherlands." International Child Welfare Review 19 (1966): 183-90.

Devoney, Catherine, M. Guralnick, and H. Rubin. "Integrating Handicapped and Non-handicapped Pre-school Children Effects on Social Play." Childhood Education 50 (1974): 360-64.

Donahue, Daniel. "Establishment of Day Care Programs for the Mentally Retarded." Child Welfare 9 (Nov. 1971): 519-23. Fredericks, B. et al. "Integrating the Moderately and severely Handicapped Preschool Child Into a Normal Day Care Setting." Early Intervention and the Integration of Handicapped and Non-handicapped Children. Ed. Michael Guralnick. Baltimore: University Park Press, 1978. 191-206. 
Guralnick, M. J. "The Value of Integrating Handicapped and Nonhandicapped Preschool Children." American Journal of Orthopsychiatry. 46 (1976): 236-45.

Kurvant, Charito and others. Effects on Children of the Organization and the Design of the Day Care Physical Environment: Appropriateness of the Inter Agency Day Care Requirements. Dept. of Health, Education and Welfare, Washington, DC, Aug. 1976. Oregon. Legislative Assembly. Oregon Revised Statues. Legislative Counsel Committee Vol. 3A 1985.

Sande, Clay and Irene Nassor. Non-Categorical Early Childhood Program for Handicapped Children: A Model and Demonstration Project. Bureau of Education for the Handicapped, Washington, DC, 1980. Sauer, Ruth Barrymore. Handicapped Children and Daycare. Bank Street College of Education, New York, NY, March 1975.

U.S. Dept. of Education. Seventh Annual Report to Congress on Implementation of the Education of the Handicapped Act. 1985. Suarez, Tanya M. and James O. Cox. An Input Evaluation of Three Technical Assistance Needs Assessment Strategies. North Carolina University, Chapel Hill, Office of Special Education Rehab. Services, Washington, DC, March 1981.

Thelon, Janis and others. A Regional Approach to the Coordination and Delivery of Services to Preschool Handicap Children and Their Parents. Office of Education, Washington, DC, 1979. 
Wolfensberger, w. "Normalizing Activation for the Profounding Retarded and/or Multiply Handicapped." The Principle of Normalization in Human Services. Nolt Institute on Metal Retardation, Toronto, Canada (1972: 122-35. 